\author{
State University of Medan \\ e-ISSN : 2622-4968, p-ISSN : 2622-1349 \\ IJCST-UNIMED, Vol. 02, No. 1, Page; 84-89
}

Received : Desember 15, 2018 Accepted : Januari 25, 2018 Web Publised; January 28, 2019

\title{
Potential of Bio-briquette of Pineapple Crown Waste (Ananas comosus (L.) merr)
}

\author{
Kurnia Nur Addina*, Lazulva \\ Universitas Islam Negeri Sultan Syarif Kasim Riau, Panam, Pekanbaru - 28293, Indonesia \\ *E-mail: Kurnia11nuraddina@gmail.com
}

\begin{abstract}
This study aims to determine the potential of pineapple crown waste to be used as natural fuel in the form of biobriquettes, The research method used in this study is an experimental method. The research carried out in several stages, namely collection of raw materials, dehydration of raw materials, carbonization, crushing and screening, mixing binder, molding and compressing, drying and briquettes quality determining. The research findings showed that the bio-briquette quality of pineapple crown was $5.2-2.2 \%$ based on water content test, kabout 200-150 minutes, heating a liter water wiyh 200 grams bio-briquette was 23-15 minutes. All results of bio-briquette quality test of pineapple crown passed the SNI 06-3730-1995.
\end{abstract}

Keywords: Bio-briquette, Pineapple Crown, Crude Oil

\section{Pendahuluan}

Indonesia sebagai negara agraris banyak menghasilkan limbah pertanian berupa biomassa yang kurang termanfaatkan. Di sisi lain, biomassa menjadi perhatian karena kelebihannya seperti mudah dijumpai dan harganya murah. Limbah pertanian tersebut dapat diolah menjadi suatu bahan bakar padat yang lebih luas penggunaannya sebagai bahan bakar alternatif.

Salah satu tumbuhan yang ada di Indonesia adalah tumbuhan nanas. Nanas banyak ditanam di berbagai perkebunan di Indonesia. Selain itu, nanas merupakan tumbuhan yang dapat tumbuh di hampir semua jenis tanah pertanian, termasuk iklim basah maupun kering. Riau adalah salah satu daerah yang dominan menghasilkan nanas. Hal ini dikarenakan provinsi ini memiliki iklim tropis basah dengan rata-rata hujan berkisar antara 1300-3500 mm per tahun yang dipengaruhi oleh musim kemarau dan musim hujan. Berdasarkan data Badan Pusat Statistik Indonesia tahun 2012, produksi nanas di Riau sebanyak 92.445 ton, di mana kabupaten
Kampar menghasilkan 38.182 ton buah nanas. Banyaknya produksi nanas di Riau dan kabupaten Kampar khususnya, semakin banyak pula limbah yang dihasilkan dari proses pengolahan nanas tersebut, salah satu limbah yang dihasilkan adalah mahkota nanas.

Usaha untuk mencari bahan bakar alternatif yang dapat diperbarui (renewable), ramah lingkungan dan bernilai ekonomis perlu terus dilakukan karena ketersediaan bahan bakar minyak bumi terbatas dan sifatnya tidak terbarukan, sehingga diprediksikan akan terjadi kelangkaan bahan bakar minyak dan menimbulkan adanya krisis energi dan kebutuhan minyak bumi yang semakin besar merupakan tantangan yang perlu diantisipasi. ${ }^{2}$ Salah satu caranya adalah dengan membuat bahan bakar alternatif berupa biobriket.

Biobriket merupakan salah satu jenis bahan bakar yang dibuat dari aneka macam bahan hayati atau biomassa, misalnya kayu, ranting, daundaunan, rumput, jerami, kertas maupun limbah pertanian lainnya yang dapat dikarbonisasi. ${ }^{3}$ Dalam 
penelitian ini, biomassa yang digunakan adalah dari limbah mahkota nanas.

Manfaat mahkota nanas ini dapat digunakan sebagai bahan baku pembuatan biobriket karena kadar selulosa mahkota nanas terdiri dari $57,83 \% .^{4}$ Selama ini masyarakat hanya mengkonsumsi daging nanasnya saja sedangkan untuk mahkota nanas tersebut biasanya langsung dibuang atau tidak digunakan lagi. Khususnya di sepanjang jalan desa Rimbo Panjang, kecamatan Tambang, kabupaten Kampar, pedagang nanas biasanya menjual buah nanas dengan membuang mahkotanya dan ditumpuk di pinggir jalan sehingga menjadi limbah yang dapat mengganggu pemandangan serta menimbulkan bau yang tidak sedap. Oleh karena itu, akan sangat baik apabila limbah mahkota nanas ini diolah menjadi benda yang lebih bermanfaat terutama dijadikan sebagai bahan bakar alternatif berupa biobriket. Berdasarkan uraian diatas, maka penulis tertarik untuk mengadakan penelitian yang berjudul "Potensi Biobriket dari Limbah Mahkota Nanas (Ananas comosus (L.) merr).

\section{Metodologi Penelitian}

\subsection{Bahan kimia, peralatan dan instrumentasi}

Bahan-bahan yang digunakan yaitu limbah mahkota nanas yang didapat dari pedagang buah nanas (di sepanjang jalan Desa Rimbo Panjang, Kecamatan Tambang, Kabupaten Kampar); tepung kanji; air; dan minyak tanah.

Alat-alat yang digunakan dalam penelitian ini yaitu: drum pertamina dan drum cat (untuk pembakaran), wadah (baskom atau panci), cetakan briket, mortar, alu, seng (untuk alas ketika menjemur), gelas ukur, grinder, cutter atau gunting, oven, kompor, cawan porselen, furnace, desikator, ayakan mesh 60 , bomb calorimeter dan timbangan analitik.

\subsection{Prosedur Penelitian \\ Persiapan Mahkota Nanas}

Limbah mahkota nanas yang telah diambil, dibersihkan dari kotoran-kotoran yang terikut lalu dilakukan pengecilan ukuran $(2-3 \mathrm{~cm})$ dengan menggunakan cutter atau gunting, dan dicuci menggunakan air bersih kemudian dikeringkan di bawah sinar matahari.

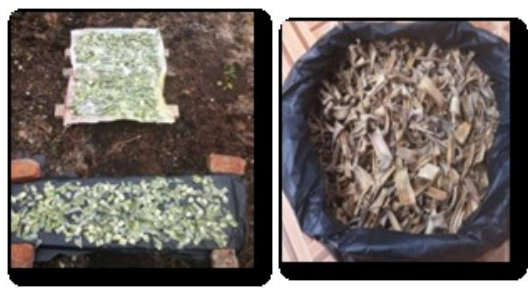

Gambar 1. Proses Penjemuran Sampel

\section{Pembuatan Arang Mahkota Nanas}

Setelah sampel mengering selanjutnya dilakukan proses karbonisasi dengan cara sampel dimasukkan ke dalam drum cat dan dilakukan karbonisasi di dalam drum pertamina. Proses karbonisasi dalam penelitian ini menggunakan drum cat yang kemudian dikarbonisasi ke dalam drum pertamina. Sehingga proses karbonisasi mahkota nanas pada keadaan tanpa udara ${ }^{5}$. Pada karbonisasi ini sampel nantinya akan diubah menjadi arang mahkota nanas.

\section{Penghalusan Arang Mahkota Nanas}

Arang yang telah dihasilkan dari proses karbonisasi ditumbuk menggunakan mortar dan alu dan dapat juga dihaluskan menggunakan grinder. Selanjutnya didapatkan sampel halus berupa bubuk arang. Kemudian bubuk arang diayak dengan ukuran 60 mesh sesuai dengan SNI 01-6235-2000.

\section{Pencetakan Biobriket Mahkota Nanas}

Perekat diperlukan dalam pembuatan biobriket. Hal ini karena sifat alami bubuk arang yang cenderung saling memisah. Pada penelitian ini, perekat yang digunakan adalah kanji.

Langkah awal pembuatan perekat adalah dengan memanaskan air. Sementara itu sediakan komposisi perekat yang telah ditentukan, yaitu 5\% (MN5), 10\% (MN10), dan 15\% (MN15) perekat di dalam sampel. Bubuk arang dan tepung kanji diaduk agar rata. Lalu ditambahkan air yang telah dipanaskan dan diaduk hingga tercampur rata. Sebelum adonan mengeras, lakukan pencetakan biobriket segera dengan menggunakan alat pencetak biobriket.Variasi komposisi perekat terhadap sampel adalah sebagai berikut:

Tabel 1. Perlakuan Proses Pencampuran dengan Bahan Perekat

\begin{tabular}{lccc}
\hline Perlakuan & Kanji (g) & $\begin{array}{c}\text { Bubuk } \\
\text { Arang (g) }\end{array}$ & Air (ml) \\
\hline MN5 & 50 & 950 & 600 \\
MN10 & 100 & 900 & 600 \\
MN15 & 150 & 850 & 600 \\
\hline
\end{tabular}




\section{Pengeringan Biobriket}

Pada penelitian ini dilakukan metode pengeringan dengan dijemur di bawah sinar matahari selama \pm 2 hari kemudian dioven, agar biobriket benar-benar kering.

\section{Metode Analisis Biobriket}

Tahapan pengujian biobriket adalah tahap melakukan uji karakteristik briket untuk mengidentifikasi apakah briket yang dihasilkan berkualitas bagus yang sesuai dengan SNI. Langkah-langkah pengujian yang dilakukan meliputi kadar abu, kadar air, nilai kalor, dan lama pembakaran.

\section{1) Kadar Air}

Penetapan kadar air dilakukan berdasarkan SNI 06-3730-1995, dilakukan dengan cara mengukur cawan porselen kosong secara konstan. Kemudian sampel sebanyak $\pm 1 \mathrm{~g}$ dimasukkan ke dalam cawan porselen dan ditimbang beratnya. Cawan yang telah berisi sampel tersebut dikeringkan dalam oven pada suhu $105 \quad{ }^{\circ} \mathrm{C}$ selama 1 jam kemudian didinginkan dalam desikator selama \pm 30 menit dan timbang kembali hingga konstan. ${ }^{6}$ Penentuan kadar air dilakukan sebanyak tiga kali pengulangan (triplo).

Perhitungan kadar air

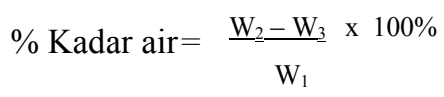

Keterangan:

$\mathrm{W}_{1}=$ Massa Sampel

$\mathrm{W}_{2}=$ Cawan + Sampel sebelum Oven

$\mathrm{W}_{3}=$ Rata-rata Akhir Cawan + Sampel Setelah Oven

\section{2) Kadar Abu}

Penentuan kadar abu dilakukan berdasarkan SNI 06-3730-1995. Dengan cara mengeringkan cawan porselen dalam tanur bersuhu $600^{\circ} \mathrm{C}$ selama 30 menit. Selanjutnya cawan didinginkan di dalam desikator selama 30 menit dan ditimbang bobot kosongnya. Kemudian ke dalam cawan kosong tersebut dimasukkan sampel sebanyak \pm 1 gram. Cawan yang telah berisi sampel selanjutnya dimasukkan ke dalam tanur dengan suhu $850^{\circ} \mathrm{C}$ selama 4 jam sampai sampel menjadi abu. Selanjutnya cawan diangkat dari dalam tanur dan didinginkan di dalam desikator, lalu ditimbang. ${ }^{7}$ Penentuan kadar abu dilakukan sebanyak tiga kali pengulangan (triplo).
Perhitungan kadar abu

$\% \operatorname{Kadar} \mathrm{Abu}=\frac{\mathrm{C}-\mathrm{A}}{\mathrm{B}} \quad \mathrm{x} 100 \%$

Keterangan:

$\mathrm{A}=$ Berat cawan kosong (gram)

$\mathrm{B}=$ Berat Sampel (gram)

$\mathrm{C}=$ Berat abu dan berat cawan setalah furnace (gram)

\section{3) Nilai Kalor}

Kalor merupakan suatu kuantitas atau jumlah panas baik yang diserap maupun dilepaskan oleh suatu benda. Dilakukan dengan Bomb Calorimeter PA C200. Dengan langkah pengerjaannya sebagai berikut:

- Ditimbang 0,86 gram sampel dan bentuk menjadi pelet, kemudian dimasukkan ke dalam cawan besi.

- Kawat nikel krom $10 \mathrm{~cm}$ dihubungkan pada batang-batang yang terdapat pada bagian dalam decomposition vessel.

- Benang katun diikatkan pada kawat dan bagian ujungnya di hubungkan pada sampel.

- Decomposition vessel diisi dengan oksigen pada tekanan 25 bar dan dimasukkan ke dalam water jacket yang berisi $2 \mathrm{Kg}$ aquades.

- Dihubungkan aliran listrik dan dimasukkan termometer ke dalam water jacket.

- Hidupkan unit digital bomb calorimeter dan diatur angka pada display menuju 0.00 dan ditekan tombol "fire", kemudian unit akan mengukur temperatur secara otomatis. Setelah display menunjukan angka konstan, nilai kalor sampel dapat ditentukan dengan menggunakan rumus ${ }^{8}$ :

$$
Q w=\frac{(\varepsilon \times \theta)-Q_{\text {ign }}-Q_{\text {fuse }}}{M_{f}}
$$

Keterangan:

$$
\begin{aligned}
\mathrm{Qw}= & \text { Nilai Kalor } \\
\varepsilon & =10.708,782 \mathrm{~J} / \mathrm{K} \\
\theta & =\text { Corrected Temperature pada Digital } \\
& \text { Data Bom Calorimeter }(\mathrm{K}) \\
\mathrm{Q}_{\text {ign }}= & \text { Nilai Kalori Wire } \\
= & \text { Mw } \times \mathrm{Qw} \\
= & 0.005 \mathrm{~g} \times 1402,2 \mathrm{~J} / \mathrm{g} \\
= & 7.011 \mathrm{~J} \\
\mathrm{Q}_{\text {fuse }}= & \text { Mc } \times \mathrm{Qc} \\
= & 0.010 \mathrm{~g} \times 17496.6 \mathrm{~J} / \mathrm{g} \\
= & 174.966 \mathrm{~J} \\
\mathrm{M}_{\mathrm{f}}= & \text { Massa Fuel }
\end{aligned}
$$




\section{4) Uji Pembakaran Biobriket}

Hubungan Komposisi Biobriket Mahkota Nanas terhadap Lama Pembakaran

Pengujian lama nyala api dilakukan dengan cara biobriket dibakar seperti pembakaran terhadap arang. Pencatatan waktu dimulai ketika biobriket menyala hingga briket habis atau telah menjadi abu. Pengukuran waktu ini menggunakan stopwatch ${ }^{9}$.

\section{Biobriket sebagai Bahan Bakar untuk Memasak 1 Liter Air}

Pengujian dilakukan dengan menghitung berapa menit yang dibutuhkan untuk mendidihkan air sebanyak satu liter terhadap biobriket sebanyak 200 gram $^{10}$. Pengukuran ini menggunakan stopwatch.

\section{Hasil dan Diskusi}

\subsection{Analisis hasil Karakterisasi \\ Hasil Pengujian Biobriket}

Tahapan pengujian biobriket adalah tahap melakukan uji karakteristik briket untuk mengidentifikasi apakah briket yang dihasilkan berkualitas bagus yang sesuai dengan SNI. Langkah-langkah pengujian yang dilakukan meliputi kadar abu, kadar air, nilai kalor, dan lama pembakaran.

Pencetakan biobriket dalam penelitian ini menggunakan tuas besi sederhana, sehingga tekanan dari alat tersebut akan memberikan bentuk biobriket sesuai wadah yang telah disediakan yaitu berbentuk silinder dengan tinggi $3 \mathrm{~cm}$ dan diameter $2,5 \mathrm{~cm}$.

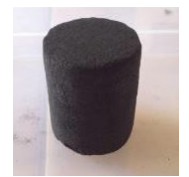

(a)

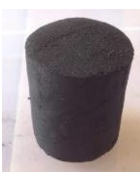

(b)

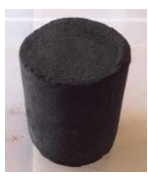

(c)
Gambar 2. Hasil Pencetakan Biobriket (a) Perekat 5\% (MN 5); (b) Perekat 10\% (MN 10); (c) Perekat 15\% (MN 15).

\section{Kadar Air}

Kadar air merupakan salah satu faktor yang mempengaruhi kualitas biobriket mahkota nanas yang dihasilkan. Semakin tinggi kadar air pada biobriket maka semakin rendah nilai kalor dan daya pembakarannya, begitu pula sebaliknya. Hal ini disebabkan energi yang dihasilkan akan banyak terserap untuk menguapkan air. Adapun hasil kadar air yang diperoleh adalah sebagai berikut:
Tabel 2. Perbandingan Kadar Air Biobriket Mahkota Nanas dengan SNI

\begin{tabular}{lll}
\hline \multicolumn{2}{l}{ Mahkota Nanas } & SNI \\
\hline MN 5 $=2,2 \%$ & & $<8 \%$ \\
\hline MN 10 $=3,7 \%$ & \\
\hline MN 15 $=5,2 \%$ & \\
\hline
\end{tabular}

Pada Tabel 2. dapat dilihat bahwa semakin tinggi kadar perekat kanji maka kadar air biobriket yang diperoleh semakin tinggi. Hal ini disebabkan karena sifat perekat kanji dan arang yang higroskopis sehingga mudah menyerap air dari udara. Pada penambahan perekat yang semakin tinggi menyebabkan air yang terkandung dalam perekat akan masuk dan terikat dalam pori-pori arang, selain itu penambahan perekat yang semakin tinggi akan menyebabkan biobriket mempunyai kerapatan yang semakin tinggi karena konsentrasi bahan perekat sebagai pengikat arang semakin banyak. Sehingga pori-pori biobriket semakin kecil dan pada saat dikeringkan, air yang terperangkap di dalam pori biobriket sukar menguap.

\section{Kadar Abu}

Kadar abu sangat berpengaruh terhadap nilai kalor. Salah satu unsur penyusun abu adalah silika. Pengaruhnya kurang baik terhadap nilai kalor briket arang yang dihasilkan. Kadar abu yang tinggi dapat menurunkan nilai kalor briket arang sehingga kualitas briket arang tersebut menurun ${ }^{11}$. Adapun hasil kadar abu yang diperoleh adalah sebagai berikut:

Tabel 3. Perbandingan Kadar Abu Biobriket Mahkota Nanas dengan SNI

\begin{tabular}{|c|c|}
\hline Mahkota Nanas & SNI \\
\hline MN $5=2,12 \%$ & \multirow{3}{*}{$<8 \%$} \\
\hline $\mathrm{MN} 10=2,74 \%$ & \\
\hline $\mathrm{MN} 15=3,20 \%$ & \\
\hline
\end{tabular}
biobriket mahkota nanas semakin tinggi dengan meningkatnya kadar perekat kanji. Hal ini disebabkan adanya penambahan abu dari perekat kanji yang digunakan. Semakin tinggi kadar perekat maka kadar abu yang dihasilkan pada biobriket semakin tinggi pula. Selain itu, tingginya kadar abu pada biobriket juga dipengaruhi oleh tingginya kandungan bahan anorganik yang terdapat pada tepung kanji dan kadar abu dari serat nanas $^{12}$.

\section{Nilai Kalor}

Nilai kalor sangat menentukan kualitas biobriket yang dihasilkan. Semakin tinggi nilai kalor pada biobriket maka semakin tinggi juga 
kualitas biobriket yang dihasilkan. Nilai kalor perlu diketahui untuk mengetahui nilai panas pembakaran yang dapat dihasilkan oleh briket sebagai bahan bakar ${ }^{13}$. Adapun hasil kadar abu dari biobriket mahkota nanas yang diperoleh adalah sebagai berikut:

Tabel 4. Perbandingan Nilai Kalor Biobriket Mahkota Nanas dengan SNI

\begin{tabular}{|c|c|c|}
\hline & Mahkota Nanas & SNI \\
\hline MN 5 & $=5582,70 \mathrm{kal} / \mathrm{g}$ & \\
\hline MN 10 & $=5464,11 \mathrm{kal} / \mathrm{g}$ & $\geq 5000 \mathrm{kal} / \mathrm{g}$ \\
\hline
\end{tabular}

Berdasarkan Tabel 4. dapat dilihat bahwa nilai kalor biobriket mahkota nanas terendah sebesar $5330,69 \mathrm{kal} / \mathrm{g}$ pada sampel biobriket dengan komposisi perekat $15 \%$. Sedangkan nilai kalor tertinggi sebesar 5582,7 $\mathrm{kal} / \mathrm{g}$ pada sampel biobriket dengan konsentrasi perekat 5\%. Sehingga konsentrasi perekat yang ditambahkan sangat berpengaruh terhadap nilai kalor biobriket, semakin tinggi persentase perekat kanji maka nilai kalornya akan semakin rendah. Begitupula sebaliknya, semakin rendah persentase perekat kanji maka nilai kalornya akan semakin tinggi. Hal ini disebabkan oleh beberapa faktor, diantaranya adalah kadar air yang terdapat pada bahan perekat cukup tinggi, sehingga semakin banyak perekat yang ditambahkan maka semakin banyak kadar air yang terdapat pada briket dan dapat menurunkan nilai kalor.

\section{Lama Pembakaran}

Waktu nyala biobriket sangat mempengaruhi kinerja suatu biobriket yang dihasilkan, karena diharapkan biobriket yang dihasilkan dapat mengalami proses pembakaran yang cepat dan nyala api yang lama. Adapun hasil dari uji coba lama pembakaran biobriket mahkota nanas adalah sebagai berikut:

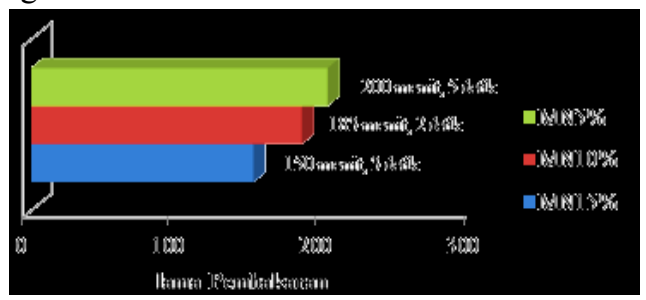

Gambar 3. Hubungan komposisi biobriket Mahkota Nanas terhadap lama pembakaran

Pada Gambar 3. dapat dilihat nyala api yang lama terdapat pada perlakuan penambahan perekat
$5 \%$ pada biobriket mahkota nanas yaitu selama (200 menit, 5 detik) dan nyala api yang cepat terdapat pada perlakuan perbandingan biobriket dengan penambahan perekat $15 \%$ yaitu selama (150 menit, 3 detik). Jadi, semakin rendah komposisi perekat maka semakin lama waktu pembakaran biobriket mahkota nanas. Nyala aoi yang dihasilkan dari biobriket mahkota nanas adalah merah, seperti dapat dilihat pada Gambar 4 .

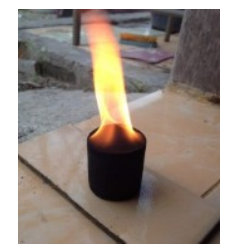

Gambar 4. Warna Nyala Api Biobriket Mahkota Nanas

Dari hasil pengujian biobriket mahkota nanas untuk kadar air, kadar abu dan nilai kalor seluruhnya memenuhi standar SNI 06-3730-1995. Dimana dari hasil uji kualitas biobriket dari mahkota nanas secara keseluruhan yang paling baik adalah biobriket dengan variasi komposisi perekat 5\%. Hal ini disebabkan karena biobriket dengan komposisi perekat yang kecil akan lebih sedikit menyerap air dari udara. Semakin kecil kadar air dan kadar abu dalam suatu bahan bakar maka nilai kalor yang dihasilkan akan semakin besar.

\section{Kesimpulan}

Kualitas biobriket mahkota nanas dengan variasi komposisi perekat berdasarkan hasil uji dari kadar air, kadar abu, nilai kalor dan lama pembakaran $200 \mathrm{~g}$ memenuhi standar SNI 063730-1995 dengan kualitas terbaik terdapat pada variasi komposisi perekat 5\%. Dengan berdasarkan hasil uji dari kadar air adalah 2,2\%, kadar abu $2,12 \%$, nilai kalor $5582 \mathrm{kal} / \mathrm{g}$, lama pembakaran (200 menit, 5 detik), dan pemanasan 1 liter air dengan $200 \mathrm{~g}$ biobriket selama 23 menit.

\section{Acknowledgement}

Puji syukur penulis ucapkan kepada Allah SWT yang telah melimpahkan rahmat dan hidayahNya, sehingga penulis dapat menyelesaikan penelitian ini. Serta pada baginda Nabi Muhammad SAW yang menjadi inspirasi bagi kami, para umatnya.

Selanjutnya, penulis ucapkan terimakasih kepada Kepala labor dan laboran laboratorium; Laboratorium Pendidikan Kimia Universitas Islam 
Negeri Sultan Syarif Kasim Riau, Laboratorium Ilmu Nutrisi dan Kimia Fakultas Pertanian dan Peternakan Universitas Islam Negeri Sultan Syarif Kasim Riau, Laboratorium Material dan Nanoteknologi FMIPA Universitas Riau, Laboratorium Konversi Energi Fakultas Teknik Universitas Riau.

\section{Referensi}

1. D. Hartini. "Produksi Nanas. Internet: http://kidnesia.com/Indonesiaku/TeropongDae $\mathrm{rah} /$ Riau/Flora/Produksi-Nanas-Di-Riau, $\quad[12$ desember 2016]

2. J. Erwin, J. P. Pane, dan N. Herlina. (2015, Juni). Pengaruh Suhu dan Waktu Karbonisasi terhadap Nilai Kalor dan Karakteristik pada Pembuatan Bioarang Berbahan Baku Pelepah Aren (Arenga Pinnata). Jurnal Teknik Kimia. 4(2). hlm. 46.

3. S. D. Atika. (2014, Maret). Implementasi Pengolahan Briket Bio-Arang Limbah Ampas Tebu pada Pembelajaran Kimia Materi Hidrokarbon Berbasis Pendekatan Saintifik dengan Metode Proyek. Karya Ilmiah Universitas Tanjung Pura. hlm. 5.

4. Susana. (2011). Ekstraksi Selulosa Limbah Mahkota Nanas. Jurnal Vokasi. 7(1). hlm. 91.

5. S. N. Yanda. Potensi Kulit Jengkol sebagai Biobriket untuk Alternatif Sumber Belajar pada Materi Senyawa Hidrokarbon di Sekolah Menengah Atas Negeri 1 dan Sekolah Menengah Atas Negeri 2 Tembilahan. Skripsi UIN Suska Riau. 2016.

6. Riyadi. S.T Dwiyati, dan A. K. Abdi Ilahi (2016). Charcoal Briquettes Characteristics of HDPE Mixed with Water Hyacinth, Coconut Shell, and Bagasse" jurnal of Energy Engineering, 6(3). hlm. 45.

7. Maryono, Sudding, dan Rahmawati. (2013, Juni). Pembuatan dan Analisis Mutu Briket Arang Tempurung Kelapa Ditinjau dari Kadar Kanji. Jurnal Kimia FMIPA. 14(1). hlm. 77.

8. D. Patabang. (2012, Juli). Karakteristik Termal Briket Arang Sekam Padi dengan Variasi Bahan Perekat. Jurnal Mekanika. 3(2). hlm. 289.

9. Santosa, Mislaini R., S. P. Anugrah. Studi Variasi Komposisi Bahan Penyusun Briket dari Kotoran Sapi dan Limbah Pertanian”. Jurnal Teknik Pertanian. hlm. 9.

10. Suhartoyo dan Rahmad. (2016). Effektifitas Biobriket Limbah Biomass sebagai Bahan Bakar Ramah Lingkungan Skala Rumah Tangga. Jurnal Teknik Elektro Akademi Teknologi. hlm. 111.

11. D. Patabang. (2011, Januari). Studi Karakteristik Termal Briket Arang Kulit Buah Kakao. Jurnal Mekanikal. 2(1). hlm. 26.

12. J. Erwin, J. P. Pane, dan N. Herlina, Op. Cit., hlm. 49.

13. Y. Ristianingsih, A. Ulfa, dan R. Syafitri K.S. (2015, Oktober). Pengaruh Suhu dan Konsentrasi Perekat terhadap Karakteristik Biobriket Bioarang Berbahan Baku Tandan Kosong Kelapa Sawit dengan Proses Pirolisis. Jurnal Teknik Kimia. 4(2). hlm. 20. 